\title{
14 The political economy of coal in light of climate and mineral-energy policies
}

\author{
A case study from Colombia
}

Lina María Puerto-Chaves and Felipe Corral-Montoya

\section{Introduction}

The rapid coal phase-out required to limit global temperature rise to $1.5^{\circ} \mathrm{C}$ above preindustrial levels is still lagging behind (Rogelj et al., 2018). Achieving this requires an early retirement of assets in coal extraction and combustion (Spencer et al., 2018). Although coal transitions are underway worldwide in both exporting and consuming countries, coal continues to play a central role in many countries' energy and economic systems (Garg \& Steckel, 2017; Gellert \& Ciccantell, 2020). Fossil fuel-dependent economies, especially those relying heavily on its exports, are facing structural challenges amidst this context (Peszko et al., 2020). For Colombia, the 5th largest steam coal exporter in the world (IEA, 2020a), the challenge of a changing global energy landscape means navigating a steep drop in international coal benchmark prices that has not only been accelerated by the COVID-19 pandemic but is likely to continue in the context of a global energy transition and more ambitious climate change mitigation commitments (Yanguas Parra et al., 2021).

In this setting, large-scale export-oriented coal extraction ${ }^{1}$ dominates Colombia's mineral-energy landscape, as $90 \%$ of coal extraction is destined for exports and only $10 \%$ is used in domestic industry and power plants (UPME, 2020a). The coal sector in Colombia is significant at a macroeconomic level since it fills important gaps in trade and fiscal deficits through coal export revenues. It also contributes to the local economies of coal extracting regions via royalties, employment, and local expenditure (Patzy, 2021; Patzy \& López, 2021). This reliance puts natural resource-based rents at stake in the volatile context of commodity markets (Peszko et al., 2020).

Current responses to this situation have focused on two strategies. First, trying to increase domestic coal demand for electricity generation as implied by the most recent National Energy Plan 2020-2050. While the plan foresees some power plant closures without specific dates, it contemplates at least $1.4 \mathrm{GW}$ of coal-fired capacity to still be online in 2050. This conflates with current plans for new coal-fired power generation units equivalent to a 1.4-GW expansion on top of the existing 1.6 GW in coal-fired capacity (Global Energy Monitor,

DOI: $10.4324 / 9781003044543-18$ 
2020; UPME, 2021a; 2021b). Second, assigning hydrocarbons and mineral extraction a pivotal role in the policy package to recover from the COVID19-induced economic crisis (Atwood \& Medina, 2021; DNP et al., 2021), and expanding the international demand horizon of Colombian coal through, amongst others, a "neutral coal" strategy in which coal exports would be directly carbon-offset via reforestation certificates to be accounted in the purchasing country's greenhouse gas (GHG) emissions inventories (Rueda, 2020).

These strategies contrast with Colombia's climate action commitments. The recently updated Nationally Determined Contribution (NDC) for the period 2020-2030 committed to a 51\% GHG emissions reduction by 2030 relative to a business-as-usual scenario in which Colombia would emit 345.90 MtCO2eq. This means emissions in 2030 should not surpass 169.44 MtCO2eq, equating to $37.5 \%$ less emissions than in the NDC's benchmark year (2015) (MADS, 2020). Despite including mitigation measures in the energy sector, and the need for a just transition of the workforce as a main pillar, the NDC does not contemplate pledges to retire or to not build additional coal-based thermoelectric capacity in the country. In addition to climate policy concerns, coal extraction in Colombia has been subject to multiple accusations and resistance by local communities, NGOs, and sourcing companies that allege weak oversight of the social, environmental, human health, and human rights conditions throughout the Colombian coal supply chain (AFR, 2021; Cardoso, 2015; Indepaz, 2018; Tierra Digna et al., 2015).

The case study is structured as follows. "Case study design" section presents how we crafted the study. "Results" section disentangles the results of our analysis and the objectives we spell out from them. "Discussion" section discusses the results and "Conclusion" section finalizes with our concluding remarks.

\section{Case study design}

Amidst this context, we aim to analyze the underlying political and economic interests around coal extraction within the mineral-energy landscape in Colombia based on the "Actors-Objectives-Context" (AOC) framework by Jakob et al. (2020a) covered in Chapter 1. The AOC framework is guided by the idea that policy outcomes are those that reflect the interests of the most influential actors. We identify the actors influencing mineral-energy policies in Colombia, the objectives that matter to them, and the context in which decision-making takes place. To craft the case study, we draw on 21 expert interviews with stakeholders from Colombia's mineral-energy landscape. ${ }^{2}$

Interviews were conducted in Bogotá during November and December 2019 following a semi-structured format and lasting one hour on average. They were conducted in most cases by both authors, helping to reduce risks of interviewer and social desirability bias. Field notes and interviews were transcribed and coded to identify objectives mentioned by interviewees, both their own, and those they attribute to decision makers. Through a triangulation process, we later unified them under three main objectives resulting from contrasting 
respondents' statements with official documents, reports, and academic literature (Woodside, 2010). This allowed us to identify, compare, and discuss discourse and effective outcomes resulting from Colombian energy, mining, and climate policy.

\section{Results}

Based on our main data sources, we show that shifting away from coal in Colombia not only revolves around economic, technical, social, or environmental challenges, but also on political dynamics driven by actors that will be affected by coal's deliberate or unplanned decline. A variety of policymakers, public officials at the national and regional level, and incumbent actors linked to the coal sector play a significant role in Colombia's political economy of coal. ${ }^{3}$ After the triangulation process described in the previous section, we find that their main objectives are (i) maintaining revenue streams from coal extraction, (ii) guaranteeing power system reliability and security of energy supply, and (iii) managing socio-ecological conflicts.

These objectives operate in a context influenced by three crucial pillars: first, around discourses of extractive and commodity-based development (Ocampo, 2017; Strambo \& González Espinosa, 2020); second, Colombia’s historically high reliance on hydropower (Rubio \& Tafunell, 2014; Zapata et al., 2018) and the risk of planned new hydroelectric capacity additions failing in a setting of increasing climate vulnerability, as droughts threaten reliability of supply (Henao \& Dyner, 2020); third, an antagonistic relationship between government and mining companies on one side, and the actors revealing, resisting, and opposing the negative social and environmental impacts of the coal supply chain in Colombia, on the other (Corral-Montoya, forthcoming; OCMAL \& CENSAT Agua Viva, 2016). The following subsections start by briefly pointing out the contextual factors in which these objectives operate and are followed by discussing the outcomes that have been effectively brought about by Colombian climate and mineral-energy related policies.

\section{Maintaining revenue streams from coal extraction}

\section{Extractive- and commodity-based growth}

The 1980s and 1990s in Colombia brought about a shift from importsubstitution-led industrialization toward facilitating the entry and operation of foreign financial and technological capital into the extraction of nonrenewable natural resources as a main driver for development (Corral-Montoya, forthcoming; Vélez-Torres, 2014). This occurred parallel to a process of privatization and denationalization of coal extraction (OCA, 2017), amongst other sectors. Today, transnational enterprises (TNEs) have become increasingly relevant in enabling the creation of a strong coalition between the national government and the mining sector [nsa3]. Through narratives linking natural resource, and 
particularly coal extraction, to ideas of "development", "progress", or "peacebuilding” (McNeish, 2017b; Strambo \& González Espinosa, 2020), this coalition has been essential in shaping a tax incentive regime facilitating fossil fuels and minerals extraction which averaged USD 3.3 billion per year between 2010 and 2016 (Pardo Becerra, 2018).

In Colombia, most coal extraction occurs in open-pit, capital-intensive, high-impact operations in the Northeast regions of Cesar and La Guajira as seen in Figure 14.1. Since its insertion in the 1980s, large-scale coal extraction was conceived as an export-oriented activity, as no meaningful consumers of steam coal emerged in the Caribbean region and no infrastructure to transport coal inland was built (Corral-Montoya, forthcoming). Second only to hydrocarbons, coal exports have high balance of payments relevance due to, amongst others, Colombia's historically low levels of savings, as well as trade balance and fiscal deficits. This combination of deficits made it paramount for Colombia to increase its exports and attract foreign direct investment (FDI) to avoid a balance of payments and fiscal crisis [nsa3]. Coal and hydrocarbons hence represent over half of total exports and have comprised over $40 \%$ of incoming FDI since 1994 (Banco de la República, 2020; OEC, 2019).

This is closely associated with Colombia's commodity-dependence [npa1, nsa5]. UNCTAD (2019) labeled Colombia as a highly commodity-dependent country, with over $80 \%$ of exports coming from raw materials. The average share of coal in Colombia's export basket between 2010 and 2020 was $14.6 \%$ (DANE, 2020a). This has resulted in a high reliance on fiscal revenues from natural resource-intensive sectors, which are unable to generate linkages in other activities and resulting in a significant lag in manufacturing, and technology sectors (Ocampo, 2017).

\section{Coal extraction in Colombia: employment, revenues, and regional development}

Coal extraction was highlighted as a provider of foreign exchange earnings and FDI, as well as a source of employment, technical expertise, and local development [npa2, npa3, npa4, nsa5, ea3]. This discourse contours the political economy of coal in Colombia, but some interviewees mention a gap between it and the real contributions of coal extraction especially at the regional level [nsa1, nsa2, ea2]. For instance, employment opportunities in large-scale coal extraction are scarce, as only $0.9 \%$ and $1.8 \%$ of employment in Cesar and La Guajira occurs within this activity (Mintrabajo, 2020a, 2020b). Of these, many are temporal workers coming from other regions [nsa1, nsa2, ea2]. In fact, despite representing 38\% of La Guajira's population, members of the Wayuu people are marginally employed in coal mining with only $5 \%$ of Wayuu employees in the Cerrejón mine, the largest open-pit coal mine in Latin America, operated by BHP, Anglo American, and Glencore [nsa2]. Although the sector is also a source of indirect jobs with often precarious working conditions, the exact numbers are still unknown [nsa2] (CorralMontoya et al., 2021). 


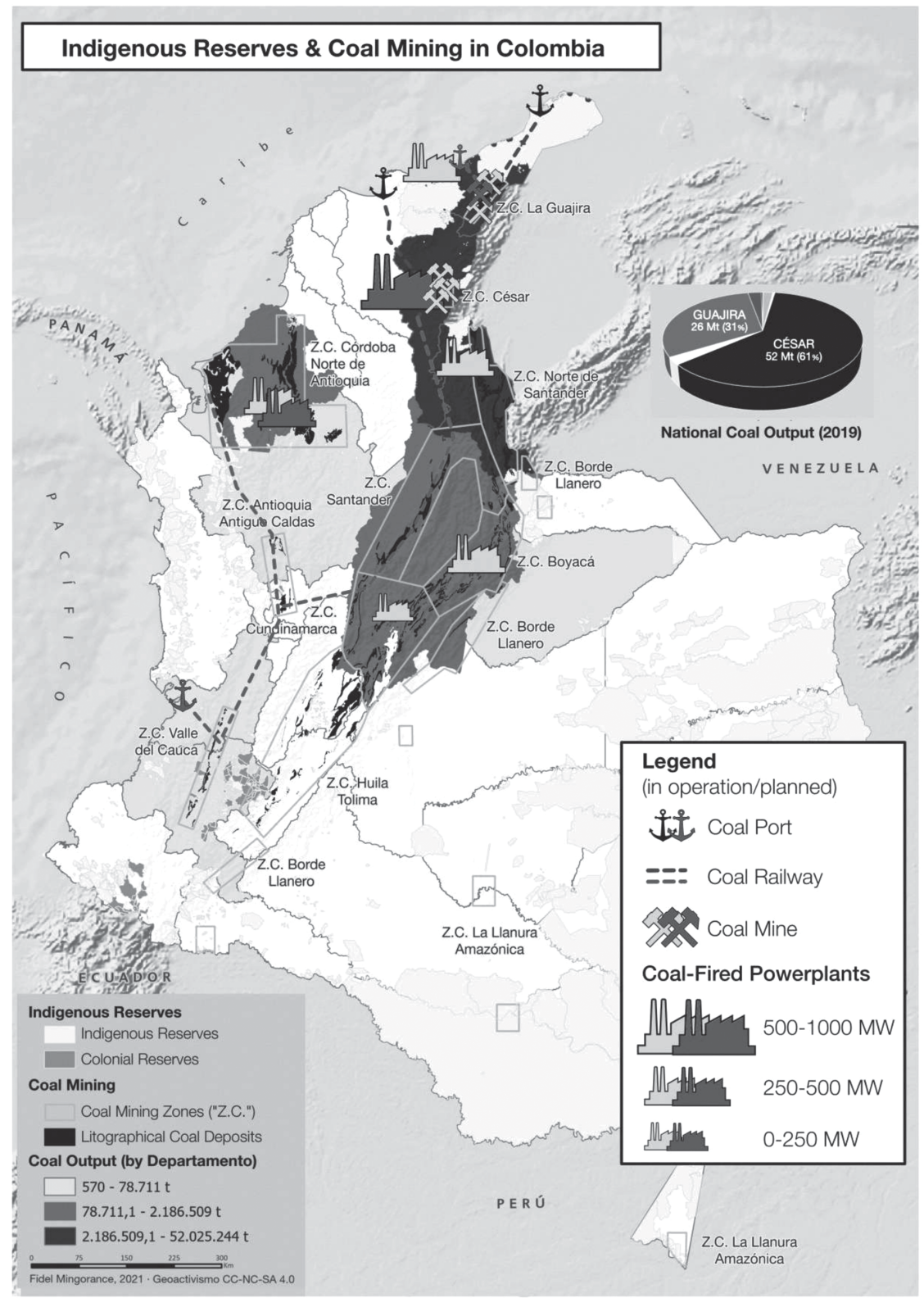

Figure 14.1 Coal mines, coal-fired power plants, and transportation infrastructure in Colombia.

Source: own elaboration based on Mingorance-HREV (2021). 
From a regional development perspective, coal plays a key role in shaping the local political economy landscape, as coal mining contributes the most to the General Royalty System (SGR by its acronym in Spanish), which invests in solving basic needs of the departamentos and municipalities [isa1, npa2, npa3]. La Guajira and Cesar are the regions that generate the most royalties from coal (85\%) (UPME, 2020b), but even after decades of mining bonanza, these regions continue to have high levels of poverty and social exclusion [isa1, nsa4, nsa9]. Nonetheless, by combining the fundamental material necessity to funnel coal rents to low-income mining municipalities, the prospects of additional revenues, and the high external vulnerability of Colombia's balance of payments position in public discourse, decision makers aim to maintain these revenue flows from coal extraction for as long as it is feasible [npa1, npa2, npa3, npa4, ea3].

\section{Appropriation of natural resource rents, and securing or expanding export markets}

The strategies to support the objective of maintaining the revenues from coal extraction stem from the idea of seizing Colombia's coal endowment to secure rents [npa4, ea3]. The discussions in this setting revolve around changing the source of rents, rather than reflecting on overcoming rent-dependency via planned approaches to diversify exports toward products that increase economic complexity [npa1, nsa7]. Considering that Colombia's coal reserves could continue to be extracted at 2017 levels for over a century (UPME, 2012; 2017), the motive of seeking to prolong and appropriate rents explains for some actors [npa3, npa4, ea3] the recent extensions of mining concessions. These extensions, according to an interviewee [npa3], were granted under a regime that provided a higher government take, understood as the sum of all government-directed payments from a natural resource extraction activity (Rudas-Lleras \& EspitiaZamora, 2013). This could also explain ongoing efforts to attract other mining conglomerates to take over the operations of companies that are suspending their activities, like Prodeco, Colombia's 3rd largest coal mining company operated by Glencore, which decided to hand back its mining titles to the government alleging the negative economic perspective from coal (Atwood \& Medina, 2021).

Both the National Mining Agency (ANM by its acronym in Spanish) and the Colombian Mining Association (ACM by its acronym in Spanish) are considering strategies to secure export markets for Colombian coal and assure that there will still be a demand for it in the short term [npa3, npa4, ea3]. However, for some actors [npa1, npa6, nsa2, nsa3, isa2], this disregards what market trends suggest, as well as Colombian coal's competitive disadvantage in the Pacific markets due to freight costs that could be almost double than those incurred for coal shipments from Indonesia or Australia (IEA, 2020b; Oei \& Mendelevitch, 2019; Yanguas Parra et al., 2021). Strategies to expand market space in countries like China, India, or Turkey have also been considered by the Ministry of Mines and Energy (MME), the ANM, and ACM [npa3, npa4, ea3]. The Colombian mining sector has also highlighted the importance of 
diversifying the country's mining basket toward copper, gold, and rare-earth extraction (Portafolio, 2020) to overcome the shrinking space of coal exports [nsa8, npa3, npa4].

\section{Guaranteeing power system reliability and security of energy supply}

Colombia's historically high reliance on hydropower

Colombia's power system is characterized for its high reliance on hydropower [nsa1, ea1, npa2, npa5, nsa7, nsa9] (Rubio \& Tafunell, 2014; Zapata et al., 2018). Since 2006 , hydropower has represented over $76 \%$ of power generation (UPME, 2020a). Droughts associated with El Niño Southern Oscillation (ENSO) have become more recurrent (Cai et al., 2014). Twice in Colombia's recent history (1992/1993 and 2015/2016), droughts caused by the ENSO phenomenon have reduced hydro-based power generation to the extreme of either causing widespread power outages or needing electricity rationing. To respond, Colombia encouraged the operation and construction of coal- and gas-fired power plants via capacity mechanisms (cargo por confiabilidad in Spanish) as a backup to hydroelectric power plants [ea1, npa2, nsa5, npa5] (Olaya et al., 2016). However, when hydrology is normal, thermal power plants operate at low capacity levels, making them financially unviable (Paredes \& Ramírez, 2017).

As the climate crisis deepens and vulnerability to extreme weather patterns increases, government and corporate voices have urged to expand (or "diversify") the power system via two strategies. The first consists of large-scale, auction-led deployment of solar and wind projects, mainly in the Caribbean region [ea1, nsa5, npa7] (MME, 2020). In Colombia, solar and wind energy already offer prices of less than 2.5 cents per $\mathrm{kWh}$ according to the results of the 2019 renewable energy auction [ea1, nsa5] (Revista Dinero, 2019). The second consists of the refurbishment or expansion of existing gas- and coal-fired power plants, together with the construction of new thermal power stations [ea1] (López-Suárez, 2020). Proponents of this strategy have pointed out the significant delays of the Hidroituango project, a 2.4-GW water dam on the Cauca River which would satisfy over $10 \%$ of Colombia's power demand (Henao \& Dyner, 2020). Since most energy planners counted on Hidroituango to be fully functional by 2019 [npa5], policymakers were quick to suggest the fast deployment of new gas- and coal-fired power plants to provide reliable electricity instead. These developments could stall additional expansion of renewables risking both renewable energy targets and climate policy commitments [nsa7, isa2] (Arango-Aramburo et al., 2020; González-Mahecha et al., 2019).

Reasons for domestic coal phase-in: security of supply and international coal market developments

Guaranteeing "security of supply" and "energy self-sufficiency" were consistently mentioned as policy priorities in Colombian energy policy [npa2, 
npa5, e1, nsa1, nsa7] (Martínez \& Castillo, 2019). This also applies to the latest National Energy Plan 2020-2050 (UPME, 2021b).Yet, this does not necessarily affect coal extraction, since TNEs responsible for almost $90 \%$ of coal extraction in Colombia export over $95 \%$ of their output.

As Figure 14.2 shows, of the coal used in Colombia, most is used for final consumption in coking plants and industrial processes (e.g. cement production, and for process heat in paper and food industries, amongst others) [npa3, npa4, npa5]. The coal used for domestic consumption is produced in the Andean region by small to medium, often informal, companies in labor-intensive, underground mines which employ over 60,000 workers (Salazar et al., 2011). As electricity generation in Colombia relies largely on hydropower (Zapata et al., 2018), coal plays a minor role in power generation.

Nevertheless, the ubiquitous threat of electricity rationing and power outages due to more extreme and frequent droughts plays an important role during the energy planning process [ea1, nsa5, npa5, nsa7, nsa9]. Expanding coal- and gas-fired generation capacity is thus invoked by trade associations ${ }^{4}$ to diversify the energy mix and provide reliability of supply (ANDEG, 2021). Similarly, they also highlight the low emissions factor of the Colombian electricity mix to justify these additions [ea3] (ibid.). For some interviewees, the role of trade associations has also been instrumental in maintaining the schemes that favor the prioritization of gas- and coal-fired power plants. For example, their active participation in the debates around the carbon tax in Colombia has been fundamental in securing the exclusion of coal and gas in the tax base so far [npa1, npa6, isa1].

Another driver for domestic coal phase-in consists of expanding a domestic market for coal. Current plans for new coal-fired power generation units in Córdoba (TermoBijao), Cesar (TermoLuna), and Norte de Santander (TermoTasajero) imply a 1.4-GW expansion on top of the existing 1.6 GW (Global Energy Monitor, 2020; UPME, 2021a; 2021b). The additional coal-fired capacity in the pipeline is considered by some actors to withstand the narrow prospects from international coal market developments [npa3, npa4, ea3].

\section{Disconnect between climate goals and mineral-energy planning instruments}

Our research indicates signs of disconnect between Colombia's climate policy instruments and its mineral-energy policy [isa1, isa2, nsa9]. For instance, the standing National Plan for Mining Development expects to increase coal extraction and prolong exports well after the 2050s [nsa8] (UPME, 2017). Further, the National Energy Plan 2020-2050 expects additions in both coaland gas-fired power plants by including 1.4 GW of coal- and 2.7 GW of gasfired power plants by 2050 and contemplates well over half of primary energy to come from fossil fuels (UPME, 2021b). Despite Colombia's commitment to carbon-neutrality by 2050, full decarbonization is still lagging behind in Colombian mineral-energy planning instruments [npa5, isa2]. 


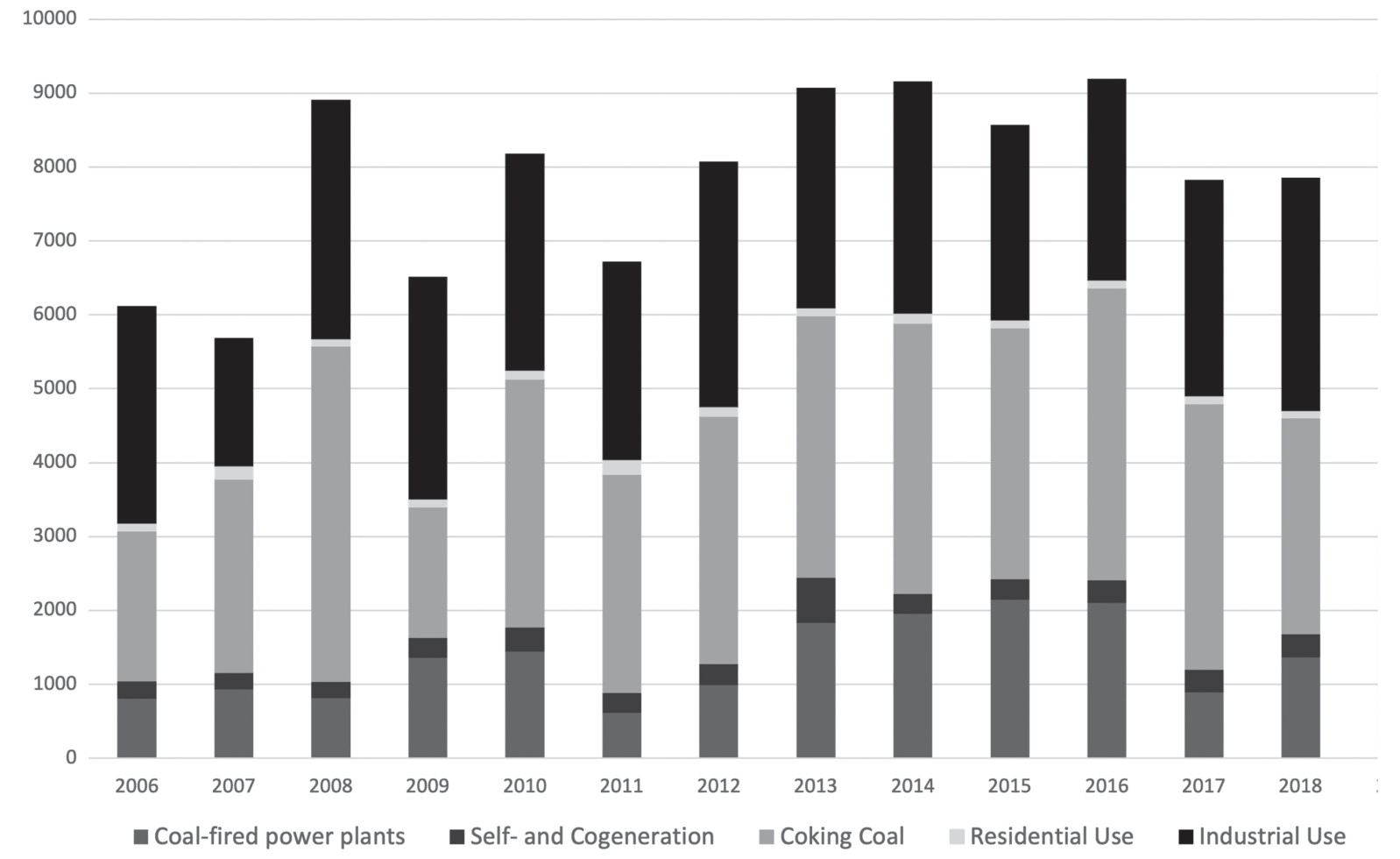

Figure 14.2 Coal consumption by sector (in kt) 2006-2019.

Source: own elaboration with data from UPME (2020a). 
If policy is executed as planned (UPME, 2021b), by 2050 Colombia will have important amounts of renewables installed [npa7]. Nevertheless, it will not have phased out fossil-fired power plants in line with its NDC commitments. In fact, according to Gonzalez-Mahecha et al. (2019), building the pipeline of coal-fired power plants in Colombia would double emissions from electricity generation. Further, from a fossil fuel supply-side perspective, Colombia's prolongation of coal extraction could make global climate protection targets even harder to achieve considering that over $80 \%$ of coal reserves must remain unburned to meet at least a $2^{\circ} \mathrm{C}$ warming limit [isa1, isa2] (Lazarus \& van Asselt, 2018; McGlade \& Ekins, 2015).

All interviewees recognized the risks and causes of climate change and considered addressing it as a top priority for all sectors and actors. However, there were significant differences with regards to concrete actions and policies. For example, some utilities are already scrambling to increase renewables in their portfolios and are invested in their deployment. At the same time, they are considering technology refurbishments to improve the efficiency of obsolete coal-fired generation instead of closing down coal-fired assets [ea1]. Some even consider coal phase-in as an adaptation measure to the vulnerability of the hydro-reliant Colombian electricity sector to more extreme and frequent droughts [npa4, ea3]. In this regard, no consideration is given to how increasing temperatures and water availability could also affect the efficiency and cooling capacity of thermal power plants (Van Vliet et al., 2016), and how the carbonintensive alternatives proposed worsen the climate crisis that they are aiming to adapt to [nsa9].

Representatives from the mining sector also recognize that climate change is caused by the combustion of fossil fuels [ea3]. Nevertheless, as coal combustion does not occur in Colombia, it is not accounted in domestic GHG emissions inventories [ea3, np4, npa7, nsa7]. This could explain the absence of strategies to phase-out or -down fossil fuel extraction in Colombia's climate policies and their disconnect with energy production [isa1] (Piggot et al., 2020). For some, continuing to bet on fossil fuel extraction and combustion is a risky strategy [npa1, isa2] as reiterated by the 2020 crash in oil prices, and the COVID-19 pandemic (Piggot et al., 2020; Yanguas Parra et al., 2021), and could even increase committed emissions from the electricity sector in Latin America (Delgado et al., 2021; González-Mahecha et al., 2019).

\section{Managing socio-ecological conflicts}

Antagonistic relationship between social actors and accumulated socio-ecological liabilities of coal extraction

Since its beginnings, local indigenous, afro-descendant, and peasant communities have opposed coal extraction and its expansion [nsa9] (EJOLT, 2019). According to Vélez-Torres (2014), this was followed by a military securitization strategy to control underground resources and guarantee an attractive 
investment environment for private FDI and modernization of production. This has resulted in a context in which government and corporate actors have an antagonistic relationship toward mining dissenters who resist the impacts of coal mining [nsa4, ea2, nsa6, nsa9].

Coal extraction in Colombia faces increasing national and international criticism [nsa4, nsa9]. As Cardoso (2015) has pointed out, socio-ecological liabilities exceed the market price of one ton of coal. A report by Tierra Digna et al. (2015) highlights some aspects of the ecological footprint of the extraction, terrestrial transport and maritime export of coal. Some of these include the severe deterioration of resources at the local level like air, water, and soil, posing significant and accumulative health risks to both workers and population adjacent to the mining activity [nsa2, nsa8, nsa4, ea2, nsa6, nsa9]. These impacts affect indigenous, afro-descendant and peasant communities disproportionately due to forced or voluntary resettlements, as well as landscape and ecosystem modifications that gradually restrict the availability of resources and natural conditions on which their traditional livelihoods and identities depend (Strambo et al., 2018; Tierra Digna et al., 2015).

Currently, the four largest coal mining companies in Colombia face accusations of human and environmental rights violations. The UN Special Rapporteur for Human Rights and the Environment has urged some of these companies, to suspend mine operations "until it can be shown to be safe" (Reuters, 2020). A complaint filed in early 2021 to the OECD will require government officials from Australia, Ireland, Switzerland, and the United Kingdom to investigate the impacts of the Cerrejón mine under the terms of the OECD Guidelines for Multinational Enterprises (AFR, 2021).

The need to address the socio-ecological conflicts around coal extraction was highlighted by both political and societal actors [nsa1, nsa2, ea1, nsa8, nsa4, nsa5, npa3, ea2, nsa6, ea3, nsa9]. It is also further acknowledged in different policy documents (MME, 2018; Ponce Muriel, 2014; UPME, 2017). However, the management approaches fluctuate between positions that consider socioecological conflicts around coal mining as barriers to development [ea1, npa2, nsa5, npa3, npa4, ea3], or as key strategies to resist the unchecked expansion of large-scale projects and its impacts [nsa1, nsa2, nsa3, nsa8, isa1, nsa4, nsa6, nsa9].

\section{Strategies to manage socio-ecological conflicts}

Since the Constitution of 1991, the legal mechanisms of "previous consultation" and "popular consultations" became key for citizens to decide on issues that are likely to affect their community [nsa8] (Dietz, 2017). Together with existing environmental legislation and different forms of strategic litigation by organized civil society, these are mechanisms to materialize the rights of participation on environmental issues, derived from international instruments like the Rio Declaration on Environment and Development (Principle 10), the Convention on Biological Diversity, and the International Labor Organization (ILO)-convention 169 [nsa4, nsa9]. However, as some interviewees mentioned, this is often seen as a barrier for development by mining companies, its associations, 
and government agencies that aim to "smoothen" and "speed-up" the pace of the expansion of projects of national and strategic interest (PINES by its acronym in Spanish), including large-scale coal extractive projects [nsa3, isa1].

The use of popular consultations grew with a widespread rejection from citizens toward extractivism (McNeish, 2017a). In fact, they were effective in banning hydrocarbon exploration from their territories. But this also meant increasing efforts to stop them [nsa4, nsa9]. For example, in 2018, the Constitutional Court stopped municipalities from proceeding with popular consultations, withholding their constitutional prerogative of autonomously deciding what activities to undertake in their territories.

In parallel, the Constitutional Court has also held coal mining companies responsible for violation of fundamental rights. Nevertheless, according to different interviews, their rulings have either lacked clear orders to change said situations or have not been implemented [nsa8, nsa9]. At the same time, the scope of previous consultation with indigenous, and afro-descendent communities has been reduced over the years, while companies have been compelled to engage in large-scale public relations and corporate-social responsibility programs to earn a "social license" to operate [nsa6] (Ponce Muriel, 2014).

\section{Threatened civil society and communities}

In Colombia, opposition to mining or infrastructure projects by local communities or civil society has been often stigmatized and even confronted with violence [nsa4, nsa6, nsa9] (OCMAL \& CENSAT Agua Viva, 2016). Since 2016, over 1000 human rights defenders and adherents to the peace process have been murdered, many of them opposing large-scale mining, infrastructure, or agroindustrial projects (Indepaz, 2020a, 2020b). Two recent reports show that Colombia is the country where the most environmental defenders are killed each year (Front Line Defenders, 2020; Global Witness, 2020).

The framing of community activists, NGOs and similarly minded groups opposing mining projects, as "enemies of progress and development" makes them targets of armed actors associated with the rents inherent to natural resource extraction [nsa4, nsa6, nsa7, nsa9]. However, ongoing judicial or scholarly inquiries have not unequivocally revealed which actors are behind it. Discussions about the transition toward a post-coal Colombian economy should engage in an intercultural dialogue that includes different approaches on territorial development, mitigation, restoration, and reparation of liabilities to overcome the lack of trust resulting from long-standing inequalities [nsa9]. Such lack of trust has been recognized in other cases of structural transformation as an aspect that could undermine transition processes (Atteridge et al., 2020).

\section{Discussion}

Coal extraction in Colombia is indeed associated with employment, revenues, and regional development (Ponce Muriel, 2014), but not necessarily as much 
as suggested by some of the political and economic actors from our dataset. We observe that many societal actors systematically question the real contributions of this activity by highlighting the manifold socio-ecological impacts associated to it, as well as the significant developmental lags in the coal extractive regions. National statistics show that the mining sector is the main economic activity of both departamentos of La Guajira and Cesar, representing 37\% and 40\% of their regional GDP, but only $0.9 \%$ and $1.8 \%$ of employment, respectively (Mintrabajo, 2020a, 2020b). Similarly, both departamentos together generate the most royalties from coal (85\%) (UPME, 2020b). However, they are still amongst the top 5, out of 32, poorest Colombian departmentos, not only in monetary terms, but also in terms of multidimensional poverty (DANE, 2020b).

In Colombia's political economy, coal actors have a diverging set of available resources and capacities to mobilize them to pursue their objectives effectively (Avelino \& Rotmans, 2009). For example, linked to the objective of maintaining revenue streams, political and economic actors have managed to mobilize resources to support coal extraction for decades to come (Atwood \& Medina, 2021). This occurs in a context in which the COVID-19 pandemic has accelerated the trend of shrinking external markets for Colombian coal. Given that a global energy transition is advancing and more ambitious climate action is being set forth toward full decarbonization, there are few prospects that demand for Colombian coal will bounce back to pre-COVID-19 levels (Yanguas Parra et al., 2021). At the same time, the market reality for Colombian coal suggests that consumers in Asia are not an option, as they are already being amply supplied, in some cases, have already increased their climate ambition, and will privilege their own coal before favoring external imports (Oei \& Mendelevitch, 2019).

Regardless of this scenario, the Economic Recovery Policy set to withstand the COVID-19-induced economic crisis reiterates its support to hydrocarbons and mineral extraction which, according to the policy document, "are relevant sectors to economic recovery due to their contributions in terms of royalties, taxes, foreign direct investment and economic considerations in favor of the nation" (DNP et al., 2021, p. 40). Similarly, to expand the horizon of Colombian coal, the ANM is currently planning a "neutral coal" strategy consisting of selling Colombian thermal coal with an associated offsetting percentage of GHG emissions for the purchasing countries (Rueda, 2020). As mentioned by the ANM, the strategy aims to maintain the income from coal extraction while advancing a just transition process and accelerating the transformation of coal-extracting territories (ibid).

Continuing to bet on coal, however, risks stranding assets on both the extraction and combustion sectors. Furthermore, additional investments in coal-fired capacities in Colombia linked to the objective of guaranteeing power system reliability and security of energy supply could increase committed emissions from the electricity sector in Latin America and imperil large economic resources to cater other necessary investments (Delgado et al., 2021; GonzálezMahecha et al., 2019). This reveals the tension between Colombia's increasingly 
ambitious climate pledges and the reality of its minerals-energy and economic recovery policies.

According to the updated version of the NDC for the period 2020-2030, the country pledged to limit emissions to 169.44 Mt of CO2eq in 2030 - a $51 \%$ reduction in comparison to the GHG emissions baseline (MADS, 2020). The power sector is one of Colombia's fastest-growing sources of GHG emissions (Crippa et al., 2019), and ca. $92 \mathrm{MtCO}_{2}$ eq came from energy use (power generation, industry, and transportation) in 2018 (Climate Watch, 2021). In this regard, Colombia's government proposed three energy-related measures seeking to mitigate 5.91-11.21 Mt of CO2eq. (MADS, 2020). These include actions to increase energy efficiency, reducing peak loads via demand-side management and diversifying the Colombian energy mix. Key government policies and initiatives have thus aimed at considerably increasing the deployment of renewable energy, mainly large-scale wind and solar parks [ea1, npa5, isa2, nsa7, npa7] (MME, 2020). Nevertheless, measures to progressively reduce coal extraction in line with the global carbon budget, or commitments to not build fossilfired power plants are absent from these discussions [isa1, isa2, nsa9]. Although the National Energy Plan 2020-2050 mentions a phase-out of inefficient and old power plants, ${ }^{5}$ neither dates nor further specifics are given (UPME, 2021b).

Concerning coal extracting regions, the prospects for a just transition are at a key juncture. Compared to the coal peak in 2017, coal extraction in Colombia had fallen by 13 million tons and exports by over 30 million tons in 2020 (see Figure 14.3) (UPME, 2020c). The steep drop not only resulted from the sharp fall in coal prices, but also from the decision to return mining titles by Prodeco, CNR's bankruptcy, and a 3-month strike at the Cerrejón mine (Patzy, 2021). Societal actors such as local stakeholders in coal extracting communities, labor unions, municipal authorities, and political actors in the opposition are concerned about an unplanned mine retirement process with weak oversight. These actors are pushing for a just transition dialogue that harmonizes mineralenergy policies with long-term decarbonization goals, which can therefore be an opportunity to successfully address the profound trust deficits stemming from long-standing inequalities and historically accumulated impacts from coal extraction.

The need for a just transition has also been pointed out by political actors in the government. For instance, in 2019 the Ministry of Labor and the ILO launched the pact for green employment and a just transition (ILO, 2019). More recently, in its updated NDC, Colombia included the just transition of the workforce toward a low-carbon and resilient economy as one of its strategic pillars (MADS, 2020). Although the guidelines of these processes are under preparation and the government has not specified which sectors will be prioritized, the current focus is to implement skills relevant for a green economy like manufacturing, construction, renewable energy, and energy efficiency (ILO, 2019). Whether the coal extraction sector, along with its workers and communities, will be prioritized within these processes is to be seen. In the meantime, the "neutral coal" strategy, still under definition by the ANM, is 


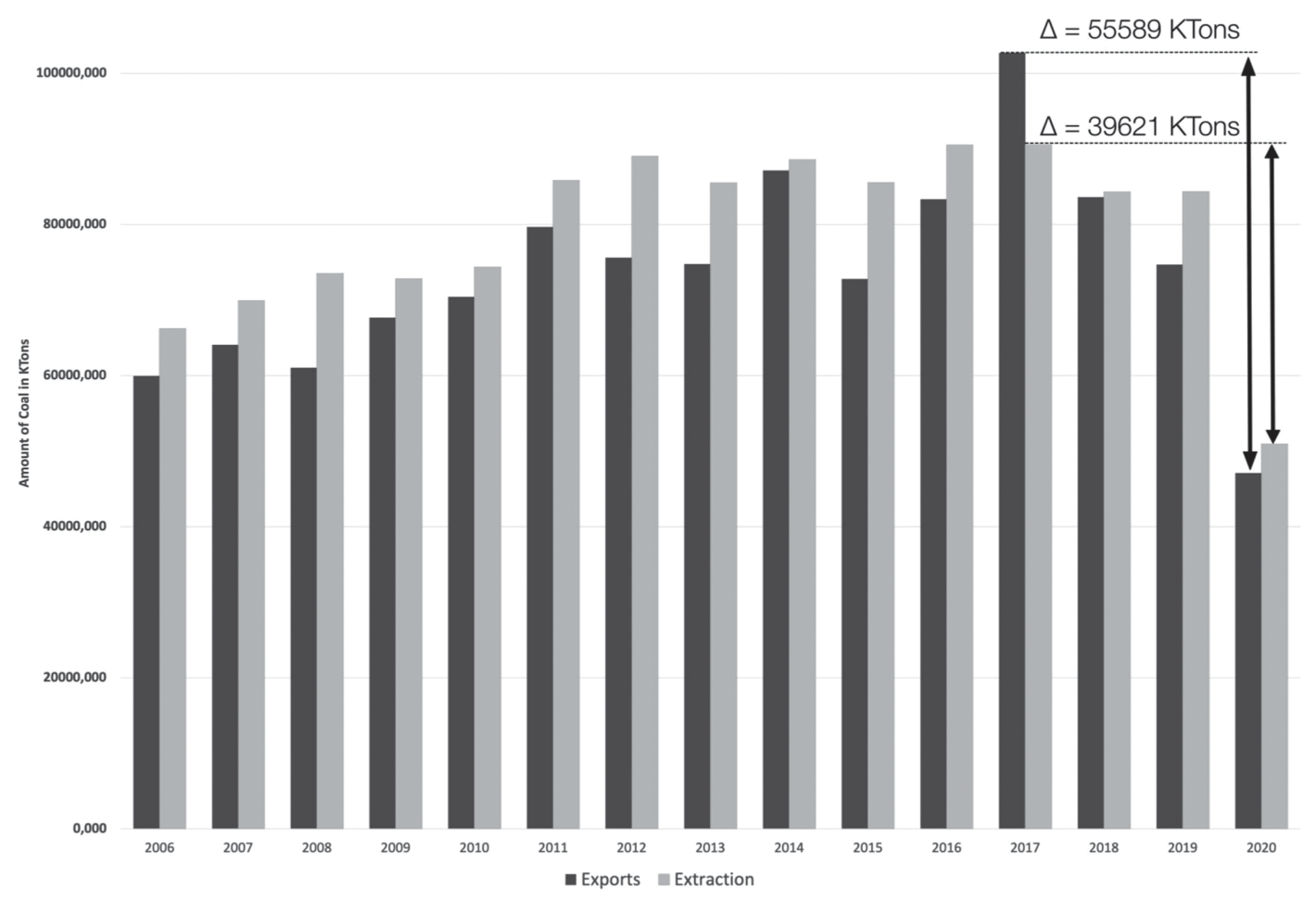

Figure 14.3 Coal extraction in Colombia since 2006.

Source: own elaboration with data from (UPME, 2020c). Extraction and export volumes for 2020 were calculated adding the data from Colombia's three main coal mining companies, Drummond, Cerrejón, and Prodeco. 
planned to fund a just transition policy based on increasing coal extraction and expanding its demand horizon.

Yet, any effort to pursue a just transition should in any case consider broadening the concept of just transition from only employment considerations toward comprehensive societal aspects like regional economic development, poverty alleviation, energy access, environmental and climate justice to ensure the transition is equitable [npa1, isa1] (Jakob et al., 2020b). Given that the costs and opportunities of the transition will not be evenly distributed among the different stakeholders, considering the interests of different actor groups may contribute to sharing the costs fairly (Atteridge \& Strambo, 2020). If the just transition is expected to be inclusive, such a process should also acknowledge and address the long-standing inequalities and accumulated negative social, environmental, and economic impacts from coal extraction as a means not only to manage, but to eventually solve socio-ecological conflicts [nsa4, nsa6], the third and last objective resulting from our research.

\section{Conclusion}

Our case study analyzed the political economy of the mineral-energy landscape in Colombia with a focus on large-scale export-oriented coal extraction. Based on the "Actors-Objectives-Context" (AOC) framework by Jakob et al. (2020a), we identified the actors, their objectives, and the context in which their interests operate. The actors influencing coal-related policies in Colombia are currently pursuing three main objectives with outcomes that reflect their resources and capabilities to mobilize them.

First, maintaining revenue streams from coal extraction was mentioned by some political and economic actors in combination with employment creation and regional development to justify the continuation of this activity. However, other societal actors question its real contributions especially in coal extractive regions that continue to have high levels of poverty, exclusion, and suffer the negative social and environmental impacts along the coal supply chain. Policy outcomes on this regard are currently resulting in the prolongation of this activity by aiming to secure or expand market space for Colombian coal.

Second, guaranteeing power system reliability and energy security is profoundly linked to Colombia's hydro-reliant and thus climate vulnerable power system. Even if solar and wind energy alternatives already offer competitive prices, some political and economic actors point out significant delays in renewables deployment to justify additions that could double current coalfired capacity. Phasing in coal is considered as another way to secure markets for domestic coal, however, it reveals a disconnect between energy planning instruments and Colombia's climate change commitments. In the context of a shrinking demand of Colombian coal, this also risks stranding assets and imperils the availability of economic resources necessary to cater the urgent investments of a post-pandemic recovery. 
Third, managing socio-ecological conflicts was identified as an important objective by both political and societal actors, despite significant differences in management approaches. For some political and economic actors, the conflicts around coal mining are seen as barriers to development. This has resulted in limiting action space for local and ethnic communities to question and resist the unchecked expansion of large-scale projects and its impacts. Societal actors, in turn, demand a more vocal role in the ongoing process to shape Colombia's energy transition and any related just transition efforts.

In the pathway toward a post-coal future in Colombia, we observed that different actor groups have historically felt and are currently experiencing, the gains and losses of the transition unevenly. Actors seeking to attain ambitious climate policies, while engaging in just transitions that are genuinely inclusive, should consider that the burdens and benefits of unfolding transitions can only be fairly shared when a truly participatory and intercultural dialogue occurs, in which actors are able to discuss different approaches on territorial development, mitigation, restoration, and reparation for the losses during the past decades of fossil fuel extraction. Understanding the political economy of coal in Colombia and the claims within the mineral-energy and climate change spectrum thus constitutes an important analytical element that may contribute to advance dialogues on a just transition.

\section{Acknowledgments}

We would like to thank all interviewees for sharing their valuable insights to make this chapter possible. We also thank the supervision of Michael Jakob and Jan C. Steckel who, along with two anonymous reviewers, helped us improve the chapter considerably. The helpful comments from the other authors of this edited book during the project workshops are also gratefully acknowledged. In particular, we thank Nicolas Malz for his excellent research assistance. We would also like to gratefully acknowledge the support of the CoalExit research project (grant number "01LN1704A" funded by the German Ministry for Education and Research) and the Transnational Centre for Just Transitions in Energy, Climate and Sustainability (TRAJECTS).

\section{Appendix}

This chapter contains supplementary online material at mcc-berlin.net/pecoal/ ch14.

\section{Notes}

1 As most coal in Colombia is extracted by a reduced group of companies for export, we conceive the constellation of actors, objectives, interests, and context to be very different for them, than for those actors linked to small-/medium-sized coal extraction companies catering for Colombia's domestic consumption (see Reasons for 
domestic coal phase-in: security of supply and international coal market developments section). This case study is focused on the former, and whenever it is necessary, we will refer explicitly to the latter.

2 Refer to the Online Appendix for the list of interviews.

3 We use the following actor classification scheme to ease their citation. Each interview is referenced in the text with the corresponding abbreviation and number as it appears on Table A14.1 in the Online Appendix.

- National political actors (NPA)

- Economic actors (EA)

- National societal actors (NSA)

- International societal actors (ISA)

4 See Table A14.2 in the Online Appendix for a detailed list.

5 Coal-fired power plants in operation have an installed capacity of $1.6 \mathrm{GW}$ and an average age of 34 years with the first units being built in 1963 and 1964 (UPME, 2016).

\section{References}

AFR. (2021). OECD adds weight to United Nations' BHP investigation. www.afr.com/ companies/energy/oecd-adds-weight-to-un-bhp-investigation-20210118-p56uz0.

ANDEG. (2021, February 16). Somos Energía Confiable. www.youtube.com/watch?v= KUDNzW1TXZI.

Arango-Aramburo, S., Ríos-Ocampo, J. P., \& Larsen, E. R. (2020). Examining the decreasing share of renewable energy amid growing thermal capacity: the case of South America. Renewable and Sustainable Energy Reviews, 119, 109648. https://doi. org/10.1016/j.rser.2019.109648.

Atteridge, A., \& Strambo, C. (2020). Seven Principles to Realize a Just Transition to A LowCarbon Economy. Stockholm: Stockholm Environment Institute.

Atteridge, A., Blanco, I., \& Strambo, C. (2020). Insights from Historical Cases of Transition: Background Paper for the EBRD Just Transition Initiative. London: European Bank for Reconstruction and Development.

Atwood, J., \& Medina, Ó. (2021, November 3). As Glencore Walks, Colombia Envisages Decades of Coal Mining. Bloomberg. www.bloomberg.com/news/articles/2021-0311/as-glencore-walks-colombia-envisages-decades-of-coal-mining.

Avelino, F., \& Rotmans, J. (2009). Power in transition: an interdisciplinary framework to study power in relation to structural change. European Journal of Social Theory, 12(4), 543-569. https://doi.org/10.1177/1368431009349830.

Banco de la República. (2020). Inversión Directa. In Estadísticas-Sector Externo. www. banrep.gov.co/es/estadisticas/inversion-directa\#gsc.tab $=0$.

Cai,W., Borlace, S., Lengaigne, M., van Rensch, P., Collins, M.,Vecchi, G., Timmermann, A., Santoso, A., McPhaden, M. J., Wu, L., England, M. H., Wang, G., Guilyardi, E., \& Jin, F.-F. (2014). Increasing frequency of extreme El Niño events due to greenhouse warming. Nature Climate Change, 4(2), 111-116. https://doi.org/10.1038/ nclimate2100.

Cardoso, A. (2015). Behind the life cycle of coal: socio-environmental liabilities of coal mining in Cesar, Colombia. Ecological Economics, 120, 71-82. https://doi.org/ 10.1016/j.ecolecon.2015.10.004.

Climate Watch. (2021). Greenhouse gas emissions and emissions targets-Colombia. www. climatewatchdata.org/countries/COL. 
Corral-Montoya, F. (forthcoming). Unveiling the political economy of fossil fuel extractivism in Colombia: tracing the process of phase-in, entrenchment, and lock-in.

Corral-Montoya, F., Santamaría, R., Brito-Mejía, A., Cardoso, A., \& Sánchez, Y. (2021). Hechos, Realidades y Perspectivas de la Minería de Carbón a Gran Escala en Cesar y La Guajira (Colombia). TU Berlin: CAJAR; Universidad del Magdalena. www. researchgate.net/publication/351097774_Hechos_realidades_y_perspectivas_de_ la_mineria_de_carbon_en_Cesar_y_La_Guajira_Colombia.

Crippa, M., Oreggioni, G., Guizzardi, D., Muntean, M., Schaaf, E., Lo Vullo, E., Solazzo, E., Monforti-Ferrario, F., Olivier, J. G., \& Vignati, E. (2019). Fossil $\mathrm{CO}_{2}$ and GHG emissions of all world countries. Luxemburg: Publication Office of the European Union.

DANE. (2020a). Cuenta del activo carbón mineral. www.dane.gov.co/index.php/estadisticaspor-tema/cuentas-nacionales/cuentas-satelite/cuenta-satelite-ambientalcsa\#cuenta-ambiental-y-economica-de-activos-de-los-recursos-minerales-yenergeticos-en-unidades-fisicas.

DANE. (2020b). Pobreza Monetaria y Multidimensional en Colombia 2019. www.dane.gov. $\mathrm{co} /$ index.php/estadisticas-por-tema/pobreza-y-condiciones-de-vida/pobreza-ydesigualdad/pobreza-monetaria-y-multidimensional-en-colombia-2019\#pobrezamonetaria-departamentos.

Delgado, R., Eguino, H., \& Lopes,A. (2021). Política Fiscal y Cambio Climático: Experiencias recientes de los ministerios de finanzas de América Latina y el Caribe. Documento para discusión. Banco Interamericano de Desarrollo.

Dietz, K. (2017). Politics of Scale and Struggles over Mining in Colombia. In Contested Extractivism, Society and the State (pp. 127-148). London: Palgrave Macmillan UK. https://doi.org/10.1057/978-1-137-58811-1_6.

DNP, Ministerio de Hacienda, Ministerio de Tecnologías de la Información y las Comunicaciones, Ministerio de Minas y Energía, Ministerio del Interior, Ministerio de Justicia y del Derecho, Ministerio de Agricultura y Desarrollo Rural, Ministerio de Salud y Protección Social, Ministerio del Trabajo, Ministerio de Comercio, Industria y Turismo, Ministerio de Educación Nacional, Ministerio de Ambiente y Desarrollo Sostenible, Ministerio de Vivienda, Ciudad y Territorio, \& Ministerio de Ciencia, Tecnología e Innovación. (2021). Política Para La Reactivación, La Repotenciacióny El Crecimiento Sosteniblee Incluyente: Nuevo Compromiso Por El Futuro De Colombia. DNP. https://colaboracion.dnp.gov.co/CDT/Conpes/ Econ\%C3\%B3micos/4023.pdf.

EJOLT. (2019). El Cerrejón mine, Colombia | EJAtlas. Environmental Justice Atlas. https:// ejatlas.org/conflict/el-cerrejon-mine-colombia.

Front Line Defenders. (2020). Global analysis 2020. www.frontlinedefenders.org/sites/ default/files/fld_global_analysis_2020.pdf.

Garg, A., \& Steckel, J. (2017). Bridging the gap - phasing out coal. In The Emissions Gap Report 2017: A UN Environment Synthesis Report. Nairobi: United Nations Environment Programme (UNEP).

Gellert, P. K., \& Ciccantell, P. S. (2020). Coal's persistence in the capitalist worldeconomy: against teleology in energy "transition" narratives. Sociology of Development, 6(2), 194-221. https://doi.org/10.1525/sod.2020.6.2.194.

Global Energy Monitor. (2020). Global coal plant tracker. https://endcoal.org/globalcoal-plant-tracker/summary-statistics/.

Global Witness. (2020). Defending tomorrow. www.globalwitness.org/en/campaigns/ environmental-activists/defending-tomorrow/?utm_source=hootsuite\&utm_ medium=global_witness\&utm_campaign=defenders. 
González-Mahecha, E., Lecuyer, O., Hallack, M., Bazilian, M., \& Vogt-Schilb, A. (2019). Committed emissions and the risk of stranded assets from power plants in Latin America and the Caribbean. Environmental Research Letters, 14(12), 124096.

Henao, F., \& Dyner, I. (2020). Renewables in the optimal expansion of Colombian power considering the Hidroituango crisis. Renewable Energy, 158, 612-627. https:// doi.org/10.1016/j.renene.2020.05.055.

IEA. (2020a). Trade - coal 2020 - analysis. www.iea.org/reports/coal-2020/trade.

IEA. (2020b). World energy outlook-2020. IEA. www.iea.org/reports/world-energyoutlook-2020.

ILO. (2019, November 27). OIT y Ministerio del Trabajo firman pacto por los empleos verdes y la transición justa en Colombia [Noticia].www.ilo.org/lima/sala-de-prensa/WCMS_ 732750/lang--es/index.htm.

Indepaz. (2018). Si el río suena, piedras lleva: Sobre los derechos al agua y a un ambiente sano en la zona minera de La Guajira. In Indepaz ediciones. https://doi.org/10.1192/ bjp.111.479.1009-a.

Indepaz. (2020a). Informe de Masacres en Colombia Durante el 2020, con corte del 21.09.2020. Observatorio de Conflictos, Paz y Derechos Humanos de Indepaz. www.indepaz. org.co/wp-content/uploads/2020/09/Masacres-21-09-2020.pdf.

Indepaz. (2020b). Listado de homicidios lideres/as sociales y defensores/as de Derechos Humanos año desde la firma Acuerdo de Paz. Indepaz. www.indepaz.org.co/wp-content/uploads/2020/09/Para-web-listado-líderes-desde-acuerdo.pdf.

Jakob, M., Flachsland, C., Christoph Steckel, J., \& Urpelainen, J. (2020a). Actors, objectives, context: a framework of the political economy of energy and climate policy applied to India, Indonesia, andVietnam. Energy Research \& Social Science, 70, 101775. https://doi.org/10.1016/j.erss.2020.101775.

Jakob, M., Steckel, J. C., Jotzo, F., Sovacool, B. K., Cornelsen, L., Chandra, R., Edenhofer, O., Holden, C., Löschel, A., \& Nace, T. (2020b). The future of coal in a carbonconstrained climate. Nature Climate Change, 10(8), 704-707.

Lazarus, M., \& van Asselt, H. (2018). Fossil fuel supply and climate policy: exploring the road less taken.

López-Suárez, A. (2020, March 6). Con 48 térmicas se reforzará la matriz de generación eléctrica. Portafolio. www.portafolio.co/economia/con-48-termicas-sereforzara-la-matriz-de-generacion-electrica-541424.

MADS. (2020). Actualización de la Contribución Determinada a Nivel Nacional de Colombia (NDC)-2020. www4.unfccc.int/sites/ndcstaging/PublishedDocuments/Colombia \%20First/NDC\%20actualizada\%20de\%20Colombia.pdf.

Martínez, \& Castillo, O. L. (2019). Colombian energy planning-neither for energy, nor for Colombia. Energy Policy, 129, 1132-1142. https://doi.org/10.1016/ j.enpol.2019.03.025.

McGlade, C., \& Ekins, P. (2015). The geographical distribution of fossil fuels unused when limiting global warming to $2^{\circ} \mathrm{C}$. Nature, 517(7533), 187-190. https://doi.org/ 10.1038/nature14016.

McNeish, J.-A. (2017a). A vote to derail extraction: Popular consultation and resource sovereignty in Tolima, Colombia. Third World Quarterly, 38(5), 1128-1145.

McNeish, J.-A. (2017b). Extracting justice? Colombia's commitment to mining and energy as a foundation for peace. The International Journal of Human Rights, 21(4), 500-516. https://doi.org/10.1080/13642987.2016.1179031.

Mingorance-HREV, F. (2021, March 4). Territorios indígenas en Colombia (2020). geoactivismo.org. https://geoactivismo.org/territorios-indigenas-en-colombia-2020/. 
Mintrabajo. (2020a). Estadísticas Laborales Departamentales—Cesar. http://filco.mintrab ajo.gov.co/FILCO/faces/estadisticas.jsf.

Mintrabajo. (2020b). Estadísticas Laborales Departamentales—La Guajira. http://filco.min trabajo.gov.co/FILCO/faces/estadisticas.jsf.

MME. (2018). Plan Integral de Gestión de Cambio Climático del sector minero energéticoPIGCCme-Mitigación. https://pigccme.minenergia.gov.co/public/web/mitigac ion\#objetivoMitigacion.

MME. (2020). La transición energética de Colombia-Memorias al Congreso. Ministerio de Minas y Energía. www.minenergia.gov.co/documents/10192/24226685/ MemoriasCongresoMME-2020.pdf.

OCA. (2017). Minería de Carbón: Drummond-Prodeco-Murray Energy-Cesar Análisis Dinámica de Actores \& Acciones (pp. 1-35). Observatorio de Conflictos Ambientales Instituto de Estudios Ambientales (Universidad Nacional de Colombia). https://con flictos-ambientales.net/oca_bd/media_references/download/1564.

Ocampo, J. A. (2017). Commodity-led development in Latin America. In Alternative Pathways to Sustainable Development: Lessons from Latin America (pp. 51-76). Geneva, Boston: Graduate Institute Publications, Brill Nijhoff.

OCMAL \& CENSAT Agua Viva. (2016). Minería, Violencia y criminalización en América Latina. Dinámicas y Tendencias. https://censat.org/es/publicaciones/mineria-violen cia-y-criminalizacion-en-america-latina.

OEC. (2019). What does Colombia export? (2017). In The Observatory of Economic Complexity. https://atlas.media.mit.edu/en/visualize/tree_map/hs92/export/col/ all/show/2017/.

Oei, P.-Y., \& Mendelevitch, R. (2019). Prospects for steam coal exporters in the era of climate policies: a case study of Colombia. Climate Policy, 73-91. https://doi.org/ 10.1080/14693062.2018.1449094.

Olaya, Y., Arango-Aramburo, S., \& Larsen, E. R. (2016). How capacity mechanisms drive technology choice in power generation: The case of Colombia. Renewable and Sustainable Energy Reviews, 56, 563-571. https://doi.org/10.1016/j.rser.2015.11.065.

Pardo Becerra, L. Á. (2018). El "regalito" tributario a las compañías de minas y petróleos: US 3.300 millones anuales. Razón Pública. www.razonpublica.com/ index.php/econom-y-sociedad-temas-29/11153-el-regalito-tributario-a-lascompañías-de-minas-y-petróleos-us-3-300-millones-anuales.html?utm_source= MadMimi\&utm_medium $=$ email\&utm_content $=E l+$ panorama + electoral + en + segunda+vuelta $\% 3 \mathrm{~A}+1$.

Paredes, J., \& Ramírez, J. (2017). Energías renovables variables y su contribución a la seguridad energética: Complementariedad en Colombia. BID Banco Interamericano de Desarrollo, 1-64. https://publications.iadb.org/publications/spanish/document/ Energ\%C3\%ADas-renovables-variables-y-su-contribuci\%C3\%B3n-a-la-seguridadenerg\%C3\%A9tica-Complementariedad-en-Colombia.pdf.

Patzy, F. (2021). Colombia: Updated Assessment of the Impact of the Coronavirus Pandemic on the Extractive Sector and Resource Governance. NRGI. https://resourcegovernance.org/ analysis-tools/publications/colombia-updated-assessment-impact-coronavirus-ext ractive.

Patzy, F., \& López, S. (2021). Carbón térmico en Colombia: Implicaciones para la economía de La Guajira y Cesar. NRGI. https://resourcegovernance.org/analysis-tools/publi cations/carbon-termico-en-colombia-implicaciones-para-la-economia-de-la-guaj ira-y-cesar. 
Peszko, G., Van Der Mensbrugghe, D., Golub, A., Ward, J., Zenghelis, D., Marijs, C., Schopp, A., Rogers, J., \& Midgley, A. (2020). Diversification and Cooperation in a Decarbonizing World: Climate Strategies for Fossil Fuel-Dependent Countries. Washington DC: The World Bank.

Piggot, G.,Verkuijl, C., van Asselt, H., \& Lazarus, M. (2020). Curbing fossil fuel supply to achieve climate goals. Climate Policy, 20:8, 881-887. https://doi.org/10.1080/14693 062.2020.1804315.

Ponce Muriel, Á. (2014). Minería Moderna para el Progreso de Colombia (1st ed.). Bogota: Sector de la Minería a Gran Escala; ANDI - Cámara Asomineros; Cámara Colombiana de Minería; Federación Nacional de Productores de Carbón.

Portafolio.(2020).Cobre,oro y carbón,retosdelaAgenciadeMinería.Portafolio.co.www.portafolio. co/economia/cobre-oro-y-carbon-retos-de-la-agencia-de-mineria-542861.

Reuters. (2020, September 29). UN rights expert urges Colombia to suspend some Cerrejon mine operations. Reuters. www.reuters.com/article/us-cerrejoncolombia-idUSKBN26J38P.

Revista Dinero. (2019). Colombia se la juega por las energías renovables. Energía. www. dinero.com/pais/articulo/cuales-fueron-los-resultados-de-la-subasta-de-energiarenovable-en-colombia/278329.

Rogelj, J., Shindell, D., Jiang, K., Fifita, S., Forster, P., Ginzburg,V., Handa, C., Kheshgi, H., Kobayashi, S., Kriegler, E., Mundaca, L., Séférian, R., \& Vilariño, M. V. (2018). Mitigation Pathways Compatible with $1.5^{\circ} \mathrm{C}$ in the Context of Sustainable Development. In V. Masson-Delmotte, P. Zhai, H.-O. Pörtner, D. Roberts, J. Skea, P. R. Shukla, A. Pirani, W. Moufouma-Okia, C. Péan, R. Pidcock, S. Connors, J. B. R. Matthews, Y. Chen, X. Zhou, M. I. Gomis, E. Lonnoy, T. Maycock, M. Tignor, \& T. Waterfield (Eds.), Global Warming of $1.5^{\circ} \mathrm{C}$. An IPCC Special Report on the Impacts of Global Warming of $1.5^{\circ} \mathrm{C}$ Above Pre-Industrial Levels and Related Global Greenhouse Gas Emission Pathways, In The Context of Strengthening the Global Response to the Threat of Climate Change, Sustainable Development, and Efforts to Eradicate Poverty. www.ipcc. ch/sr15/chapter/chapter-2/.

Rubio, M. del M., \& Tafunell, X. (2014). Latin American hydropower: a century of uneven evolution. Renewable and Sustainable Energy Reviews, 38, 323-334. https:// doi.org/10.1016/j.rser.2014.05.068.

Rudas Lleras, G., \& Espitia Zamora, J. E. (2013). Participación del Estado y la sociedad en la renta minera. In L. J. Garay Salamanca (Ed.), Mineria en Colombia-Superando el model extractivista (pp. 125-174). Bogota:

Contraloría General de la República.

Rueda, C. (2020, January 7). Colombia's Efforts for Transition in Coal producing Regions. Webinar: ACT Now! Accelerating Transition in a post COVID 19 World. www. youtube.com/watch? $\mathrm{v}=\mathrm{a} 2 \mathrm{QPgTi}$ hcw\&feature $=$ emb_title.

Salazar, N., Benavides, J., Cabrera, P., Zapata, J. G., Cadena, C., Páez, M. M., Pinzón, M., Devis, L., Durán, I., Tibocha, A. M., \& Castillo, J. (2011). Pequeña y mediana minería de carbón del interior del país: Alternativa de comercialización y financiación a partir de la conformación de alianzas estratégicas. conformación de alianzas estratégicas. Bogotá Fedesarrollo.

Spencer, T., Colombier, M., Sartor, O., Garg, A., Tiwari,V., Burton, J., Caetano, T., Green, F., Teng, F., \& Wiseman, J. (2018). The $1.5^{\circ} \mathrm{C}$ target and coal sector transition: at the limits of societal feasibility. Climate Policy, 18(3), 335-351. https://doi.org/10.1080/ 14693062.2017.1386540. 
Strambo, C., \& González Espinosa, A. C. (2020). Extraction and development: fossil fuel production narratives and counter narratives in Colombia. Climate Policy, 20(8), 931-948.

Strambo, C., González Espinosa, A. C., Velasco, A. P., \& Atteridge, A. (2018). The Politics of Subsidies to Coal Extraction in Colombia. In J. Skovgaard \& H. van Asselt (Eds.), The Politics of Fossil Fuel Subsidies and their Reform (pp. 246-264). Cambridge University Press. https://doi.org/10.1017/9781108241946.016.

Tierra Digna,Torres Bobadilla,A., Rocha Gomez, J., Melo Ascencio, D., \& Peña Lizarazo, R. (2015). El Carbón De Colombia ¿quién gana, quién pierde? Minería, Comercio Global y Cambio Climático (p. 172). Centro de Estudios para la Justicia Social “Tierra Digna.” http://tierradigna.net/pdfs/informe-carbon.pdf.

UNCTAD. (2019). Commodity Dependence: A Twenty-Year Perspective. United Nations Publications issued by the United Nations Conference on Trade and Development, New York. https://unctad.org/system/files/official-document/ditccom2019d2_ en.pdf

UPME. (2012). La Cadena del Carbón. www1.upme.gov.co/estudios-realizados-ypublicaciones.

UPME. (2016). Caracterización de las plantas de generación. https://bdigital.upme.gov.co/ bitstream/001/1323/1/Informe\%20Final.pdf.

UPME. (2017). Plan Nacional de Desarrollo Minero con Horizonte 2025-Minería responsable con el territorio (Vol. 1, p. 174). Unidad de Planeación Minero-Energética. www1. upme.gov.co/simco/PlaneacionSector/Documents/PNDM_Dic2017.pdf.

UPME. (2020a). BECO - Consulta. In BECO - Balance Energético Colombiano. www1. upme.gov.co/InformacionCifras/Paginas/BECOCONSULTA.aspx.

UPME. (2020b). Carbón - Regalías (SIMCO). UPME. www1.upme.gov.co/simco/ Cifras-Sectoriales/Paginas/carbon.aspx.

UPME. (2020c). Carbón - Producción desde 2012. www1.upme.gov.co/simco/CifrasSectoriales/Paginas/carbon.aspx.

UPME. (2021a). Informe de registro de proyectos de generación Semana 11 de 2021. UPME. www.siel.gov.co/Inicio/Generaci\%C3\%B3n/Inscripci\%C3\%B3ndeproyectosdeGe neraci\%C3\%B3n/tabid/113/Default.aspx.

UPME. (2021b). Plan Energético Nacional 2020-2050: "La transformación energética que habilita el desarrollo sostenible." UPME. www1.upme.gov.co/Paginas/PlanEnergetico-Nacional-2050.aspx.

Van Vliet, M. T. H., Wiberg, D., Leduc, S., \& Riahi, K. (2016). Power-generation system vulnerability and adaptation to changes in climate and water resources. Nature Climate Change, 6(4), 375-380. https://doi.org/10.1038/nclimate2903.

Vélez-Torres, I. (2014). Governmental extractivism in Colombia: legislation, securitization and the local settings of mining control. Political Geography, 38, 68-78. https:// doi.org/10.1016/j.polgeo.2013.11.008.

Woodside, A. (2010). Case Study Research: Theory, Methods and Practice (1st ed.). Bingley: Emerald Group Publishing Limited.

Yanguas Parra, P., Hauenstein, C., \& Oei, P.-Y. (2021). The death valley of coal - modelling COVID-19 recovery scenarios for steam coal markets. Applied Energy, 288, 116564. https://doi.org/10.1016/j.apenergy.2021.116564.

Zapata, S., Castaneda, M., Garces, E., Franco, C. J., \& Dyner, I. (2018). Assessing security of supply in a largely hydroelectricity-based system: the Colombian case. Energy, 156, 444-457. https://doi.org/10.1016/j.energy.2018.05.11. 